\begin{tabular}{|c|c|}
\hline Title & $\begin{array}{l}\text { Deal umination of Zeolite Beta Catalyst Under Controlled Conditions for Enhancing its A ctivity in A cylation and } \\
\text { Esterification }\end{array}$ \\
\hline Author(s) & Srivastava, Rajendra; Iwasa, Nobuhiro; Fujita, Shin-ichiro; A rai, Masahiko \\
\hline Citation & $\begin{array}{l}\text { Cataly sis Letters, 130(3-4), 655-663 } \\
\text { https://doi.org/10.1007/s10562-009-9992-0 }\end{array}$ \\
\hline Issue Date & $2009-07$ \\
\hline Doc URL & http:/hdl. handle.net/2115/38804 \\
\hline Rights & The original publication is avail able at springerlink.com \\
\hline Type & article (author version) \\
\hline File Information & 130-3-4_p655-663.pdf \\
\hline
\end{tabular}

Instructions for use 


\title{
Dealumination of Zeolite Beta Catalyst under Controlled Conditions for Enhancing Its Activity in Acylation and Esterification
}

\author{
Rajendra Srivastava, ${ }^{\S}$ Nobuhiro Iwasa, Shin-ichiro Fujita, Masahiko Arai* \\ Division of Chemical Process Engineering, Graduate School of Engineering \\ Hokkaido University, Sapporo 060-8628, Japan
}

\begin{abstract}
This work deals with the dealumination of zeolite beta (HBEA) under different conditions to optimize its catalytic performance. The dealumination was carried out either using oxalic or tartaric acid solution of different $\mathrm{pH}$ values or steaming up to $500^{\circ} \mathrm{C}$. The dealuminated zeolite samples were characterized using X-ray diffraction (XRD), $\mathrm{N}_{2}$-physisorption, ICP, ${ }^{27} \mathrm{Al} \mathrm{NMR}$ and $\mathrm{NH}_{3}$-TPD. Their catalytic activities were studied for acylation reaction of 2-methoxy naphthalene or naphthalene with acetic anhydride and esterification of benzyl alcohol with hexanoic acid. Among the dealuminated samples examined, those treated with oxalic acid or tartaric acid at $\mathrm{pH} 2$ showed high activity. The high activity can be correlated with the relative increase in the amount of strong acid sites and with the enhanced accessibility of the reactants to the active sites, which are caused by removal of extra-framework Al species on the acid treatments.
\end{abstract}

Keywords Zeolite beta. Dealumination. Acidity. Acylation. Esterification.

\footnotetext{
${ }^{\S}$ On leave from Department of Chemistry, National Institute of Technology Tiruchirappalli, Tamilnadu 620015,India._E-mail: chemi_rajendra@yahoo.co.in.

* Tel or Fax: 81-11-706-6594. E-mail: marai@eng.hokudai.ac.jp
} 


\section{Introduction}

The development of eco-friendly catalytic routes for various organic transformations is the ongoing interest of catalytic researchers [1,2]. The acid catalyzed alkylation, acylation and esterification of aromatic hydrocarbons are most important reactions used in industrial scale for the production of pharmaceuticals and fine chemicals $[3,4]$. These reactions are frequently carried out in liquid phases using metal halides or strong mineral acids. In spite of low selectivity and high corrosiveness, homogeneous acid catalysts (e.g. $\mathrm{AlCl}_{3}, \mathrm{H}_{2} \mathrm{SO}_{4}, \mathrm{HF}$ or $\mathrm{H}_{3} \mathrm{PO}_{4}$ ) are widely used [5]. Thus, there is a considerable interest for replacing strongly acidic, homogeneous, corrosive and polluting catalysts with environmentally clean heterogeneous solid acid catalysts [1-4]. A large number of zeolites such as MFI (ZSM-5), zeolite beta, zeolite Y, zeolite mordanite (MOR) have been described as active catalysts in these reactions [6].

Modification of as-synthesized zeolite samples is essential for obtaining stable and active catalysts for molecular transformations in fine chemicals synthesis. Dealumination, the removal of extra-framework Al species without destroying the microporous structure, is one of the modifications mainly utilized for improving the performance of zeolites. It has been achieved by hydrolysis of Al-O-Si bonds by mineral acids combined with steaming [7-11], complexation of aluminum with organic acids such as oxalic acid, citric acid or organic sulfonic acid [12-15], or by direct replacement of aluminum by silicon with gaseous silicon tetrachloride [16]. It has been reported that the zeolites structure, the $\mathrm{Si} / \mathrm{Al}$ ratio of the framework, the crystal size, and the number of acid sites interacting with the framework or the number of defect sites influence the dealumination behavior of an individual zeolite sample [17]. Extra-framework Al species are generally responsible for the formation of undesired products and removal of such species by acid leaching would improve the performance of the zeolites $[18,19]$. The effect of acid leaching with concentrated acid solutions is to remove framework aluminum from positions close to defect sites and from the external surface.

The large pore beta zeolite is structurally disordered and its framework structure was described as a three-dimensional intersecting channel system [20-22]. The beta crystalline structure is an intergrowth of two or three polymorphs and has high density 
of stacking defects due to partially coordinated aluminum [23]. The unique acid properties, mainly related to local defects, and the optimal pore dimensions, make zeolite beta a very promising catalyst in shape-selective organic conversions [24]. Zeolite beta is widely being studied in liquid phase organic transformations and some of the processes are being commercialized [25,26]. For carrying out various kinds of organic transformations zeolite catalysts of different acid strengths and textural properties are required. Zeolite beta is a right candidate due to its optimal pore dimensions and higher surface area [20-24].

Dealumination of zeolite beta occur very easily due to the presence of stacking defects [27]. Dealumination of zeolite beta using oxalic acid and citric acid has been reported $[14,15]$. It also have been reported that aluminum species in the solution, which are eliminated from the framework by $\mathrm{HCl}$ treatment, are easily reinserted into the framework by controlling the $\mathrm{pH}$ value of the solution $[28,29]$. Dealumination of zeolite beta with either mineral acids or organic acid causes substantial loss of crystallinity as well as catalytic activity [14]. Hence, controlled dealumination of zeolite beta to obtain high catalytic activity is highly important. Here, we report the optimization of catalytic activity of zeolite beta by controlled dealumination by either using oxalic or tartaric cid solution of different $\mathrm{pH}$ values or steaming up to $500^{\circ} \mathrm{C}$. The dealuminated zeolite beta samples of different $\mathrm{Si} / \mathrm{Al}$ ratios were characterized by various methods to monitor changes in the structural and acid properties. Their catalytic activities were tested for acylation of 2-methoxynapthalene and naphthalene with acetic anhydride and for esterification of hexanoic acid with benzyl alcohol. Then, the relationship between the structural and acid properties with the catalytic activities was investigated.

\section{Experimental}

\subsection{Catalyst preparation}

Beta zeolite of $\mathrm{NH}_{4}{ }^{+}$-form with a $\mathrm{SiO}_{2} / \mathrm{Al}_{2} \mathrm{O}_{3}$ of 9 was obtained from Catalysis Society of Japan, which was calcined at $550^{\circ} \mathrm{C}$ for $4 \mathrm{~h}$ to change into $\mathrm{H}$-form (HBEA). Several dealuminated HBEA samples were prepared by different treatments such as acid and steam treatments. All the acid treatments were conducted under different $\mathrm{pH}$ 
conditions as follows: a treatment solution was prepared by adding oxalic acid (or tartaric acid) to a $50 \mathrm{~cm}^{3}$ of double distilled water while magnetically stirring until the $\mathrm{pH}$ of the aqueous solution reached the desired value $(3,2,1.5,1)$. The acid treatment solution so prepared was used for dealumination. A $1 \mathrm{~g}$ HBEA sample was added to a $50 \mathrm{~cm}^{3}$ of the acid solution and the suspension was stirred at $60^{\circ} \mathrm{C}$ for $4 \mathrm{~h}$, filtered, and washed with hot water to remove aluminum complexes formed. Then, the solid sample was dried in air at $100^{\circ} \mathrm{C}$ for $48 \mathrm{~h}$. Those samples dealuminated with oxalic acid solutions are designated as HBEA-pH3, $-\mathrm{pH}$, - $\mathrm{pH} 1.5$, and $-\mathrm{pH} 1$, according to the $\mathrm{pH}$ value used. The dealumination was also performed in similar manners with a tartaric acid solution at $\mathrm{pH} 2$ instead of the oxalic acid solution and the sample so prepared is referred to as HBEA-pH2t. In addition, the HBEA was dealuminated by passing a mixture of steam and $\mathrm{N}_{2}\left(40 \mathrm{vol} \%\right.$ in $\left.\mathrm{N}_{2}\right)$ at $400^{\circ} \mathrm{C}$ and $500^{\circ} \mathrm{C}$ for $4 \mathrm{~h}$. Those dealuminated samples are designated as $\mathrm{HBEA}-400^{\circ} \mathrm{C}$ and $\mathrm{HBEA}-500^{\circ} \mathrm{C}$. The $\mathrm{Al}$ concentration in the zeolite samples was determined by ICP-MS.

\subsection{Sample characterization}

The structural and chemical features of various dealuminated beta zeolite samples so prepared were examined by different methods. X-ray diffraction (XRD) patterns were recorded in the $2 \theta$ range of $5-50^{\circ}$ with a scan speed of $2 \% \mathrm{~min}$ on a Rigaku X-ray diffractometer using $\mathrm{Cu} \mathrm{K \alpha}$ radiation $(\lambda=0.1542 \mathrm{~nm}, 40 \mathrm{kV}, 20 \mathrm{~mA})$ and a proportional counter detector. Nitrogen adsorption measurement at $77 \mathrm{~K}$ was performed by NOVA 1000 series Quantachrome Instruments volumetric adsorption analyzer. Samples were out-gassed at $300^{\circ} \mathrm{C}$ for $4 \mathrm{~h}$ in the degas port of the adsorption apparatus. The specific surface area was determined by BET method using the data points of $\mathrm{P} / \mathrm{P}_{0}$ in the range of about $0.05-0.3$. The pore diameter was estimated using the Barret-Joyner-Halenda (BJH) model. The state of Al species were examined by solid-state NMR using a Bruker DSX300 spectrometer with a frequency of 59.63 $\mathrm{MHz}$, a recycling delay of $600 \mathrm{~s}$, and a radiation frequency intensity of $62.5 \mathrm{kHz}$. The acid properties were examined by temperature- programmed desorption (TPD) with ammonia using a TPD-1-AT instrument (BEL Japan). Before TPD experiments, the catalyst sample was pretreated in $\mathrm{He}\left(50 \mathrm{~cm}^{3} / \mathrm{min}\right)$ at $600^{\circ} \mathrm{C}$ for $1 \mathrm{~h}$. After cooling down to $100^{\circ} \mathrm{C}$, ammonia (partial pressure 100 Torr) was passed through the samples for $1 \mathrm{~h}$. Then, the sample was subsequently flushed by He stream $\left(50 \mathrm{~cm}^{3} / \mathrm{min}\right)$ at 
$100^{\circ} \mathrm{C}$ for $1 \mathrm{~h}$ to remove physisorbed ammonia. The TPD experiments were carried out in the range of $100-600^{\circ} \mathrm{C}$ at a heating rate of $10^{\circ} \mathrm{C} / \mathrm{min}$. The ammonia concentration in the effluent was monitored by using a quadrapole mass spectrometer.

\subsection{Catalytic measurement}

The catalytic activity of various dealuminated zeolite samples was tested for acylation of naphthalene and 2-methoxy naphthalene with acetic anhydride and for esterification of benzyl alcohol with hexanoic acid using an autoclave reactor. For acylation reaction, $10 \mathrm{mmol}$ of 2-methoxy naphthalene (or naphthalene), 10-50 mmol acetic anhydride, $5 \mathrm{~g}$ of 1, 2-dichloroethane solvent, and $100 \mathrm{mg}$ zeolite catalyst were added to the reactor and the reaction was conducted at $150^{\circ} \mathrm{C}$ for $12 \mathrm{~h}$. After the reaction, the autoclave was cooled to room temperature immediately with cold water. The reaction mixture was filtered and the catalyst was washed with acetone $(5 \mathrm{ml})$ to remove all the products remaining on it. The organic products were analyzed using GC, Shimadzu GC-14B equipped with ZB-50 capillary column (30 m length x 0.25 mm inner diameter) and confirmed with GC-MS, Shimadzu GCMS-QP5050 and authentic samples obtained from Aldrich. The esterification reaction was conducted at $130^{\circ} \mathrm{C}$ for $4 \mathrm{~h}$ using benzyl alcohol $(10 \mathrm{mmol})$, hexanoic acid $(10 \mathrm{mmol})$, toluene $(2.5$ g) as solvent, and catalyst $(100 \mathrm{mg})$ in the autoclave. The post-reaction procedures were the same as used for the acylation reaction.

\section{Results and discussion}

\subsection{Physicochemical characterization}

Fig. 1 shows XRD patterns of various zeolite samples before and after dealumination via acid and steam treatments under different conditions. The XRD patterns of all the dealuminated samples are identical to that of the parent HBEA, indicating no structural changes under the dealumination conditions used. The textural properties of those samples are given in Table 1. For the samples dealuminated with oxalic acid, total surface area and total pore volume tend to increase slightly with a decrease in the $\mathrm{pH}$. External surface area of dealuminated samples was larger 
compared to parent HBEA while micropore area remains the same. When the $\mathrm{pH}$ of oxalic acid is lower (more acidic), $\mathrm{Si} / \mathrm{Al}$ ratio is larger. Only a marginal change in the textural properties was observed for steam treated samples compared to those of parent HBEA sample.

\section{Figure 1, Table 1}

${ }^{27} \mathrm{Al}$ NMR results are shown in Fig. 2 and Table 2. Fig. 2 indicates two peaks corresponding to tetrahedral and octahedral Al sites. The octahedral Al concentration tends to decrease on oxalic acid treatment and the sample treated at $\mathrm{pH} 1.5$ contains tetrahedral Al sites only. This suggests that oxalic acid treatment is effective for the removal of extra-framework Al species. The samples dealuminated with oxalic and tartaric acids at $\mathrm{pH} 2$ exhibit similar tetrahedral $\mathrm{Al}$ : octahedral $\mathrm{Al}$ ratios, which shows similar types of Al environment in those acid-treated samples. Only a marginal change in $\mathrm{Al}$ environment was observed for steam treated $\mathrm{HBEA}$ sample at $500^{\circ} \mathrm{C}$ (not shown here).

Figure 2, Table 2

The acid properties were examined by $\mathrm{NH}_{3}$-TPD. Fig. 3 gives TPD profiles of zeolite beta samples dealuminated under different conditions. All the dealuminated samples, except for the one treated with oxalic acid at $\mathrm{pH} 1.5$, show similar profiles to that of the parent HBEA, having two desorption peaks at around $180^{\circ} \mathrm{C}$ and $350^{\circ} \mathrm{C}$. It appears that the high-temperature desorption peak is stronger as compared with the low-temperature one for the samples treated with oxalic acids at $1.5 \leq \mathrm{pH}<3$. The treatment with oxalic acid at a lower $\mathrm{pH} 1.5$ significantly decreases the lowtemperature desorption and shifts the high-temperature desorption to lower temperatures with a peak centered at around $320^{\circ} \mathrm{C}$. Table 2 gives the total amount of acid sites determined by the total amount of $\mathrm{NH}_{3}$ desorbed. The amounts of weak and strong acid sites were estimated by dividing the TPD profile into two regions at a temperature of the minimum desorption between the low- and high-temperature desorption peaks. It appears that the amount of strong acid sites do not change so much on dealumination via acid and steam treatments, while that of weak acid sites 
decreases. For the sample treated with oxalic acid at the lowest $\mathrm{pH} 1.5$, the amount of strong acid sites and weak acid sites are smaller by a factor of $1 / 2$ and $1 / 10$, respectively, compared to parent HBEA sample. The low-temperature desorption is attributable to desorption from the extra-framework Al species. These Al species can be removed on the oxalic acid treatment, judging from the ${ }^{27} \mathrm{Al}$ NMR. Extraframework Al species are also removed on the tartaric acid treatment but less significantly on the steam treatments.

Figure 3

Dealumination of zeolite with oxalic acid is caused by strong coordination and complexation with the aluminum cation. The size of oxalic acid $(0.29 \times 0.54 \mathrm{~nm})$ makes its diffusion into large zeolite pores possible and can therefore effectively remove aluminum species from the lattice by forming a complex of an aluminum ion surrounded by one oxalate ion and water ligands. Fig. 4 shows a schematic representation of parent and dealuminated HBEA samples. Before dealumination, there exist both framework and extra-framework Al species. The oxalic acid treatment at $\mathrm{pH} 2$ removes most of the extra-framework $\mathrm{Al}$ species and a few framework $\mathrm{Al}$ species. However, upon severe treatment at $\mathrm{pH} 1.5$, all the extra-framework $\mathrm{Al}$ species are removed and a significant amount of framework Al species are also lost, as confirmed by ${ }^{27} \mathrm{Al} \mathrm{NMR}$ and $\mathrm{NH}_{3}$-TPD. It may be difficult to obtain an ideal dealuminated HBEA sample, in which only extra-framework Al species can be selectively removed without removing the framework Al species.

Figure 4

\subsection{Catalytic activity}

The activities of various dealuminated samples were investigated for two important reactions: (1) acylation of naphthalene and 2-methoxynapthalene with acetic anhydride and (2) esterification of benzyl alcohol with hexanoic acid.

As described later, a dealuminated sample HBEA-pH2 was found to be the best catalyst among various catalysts investigated and, hence, the reaction conditions 
for the acylation of 2-methoxynapthalene with acetic anhydride were first optimized using this sample in a solvent of 1, 2-dichloroethane. 1-acetyl, 2-methoxy naphthalene (1,2-AcMON) was formed as a major product and 2-methoxy, 6-acetyl naphthalene (2,6-AcMON) was formed as a minor product in the acylation reaction of 2-methoxynapthalene. Influence of molar ratio of 2-methoxynapthalene to acetic anhydride is shown in Fig. 5. A large difference in total conversion was observed when the ratio was changed from $1: 1$ to $1: 3$ but only a marginal increase on further change to 1:5. Fig. 6 shows the influence of solvents on the total conversion. Polar solvents, 1, 2-dichloroethane and nitrobenzene, were found to be more effective than a non-polar solvent $n$-hexane. Thus, the following acylation reactions were conducted in 1, 2-dichloroethane and at a ratio of 2-methoxynapthalene to acetic anhydride of $1: 3$.

\section{Figure 5, Figure 6}

Table 3 summarizes the results of acylation reactions of 2-methoxynapthalene with acetic anhydride over various dealuminated beta zeolite catalysts. The parent zeolite HBEA was not so active and gave a total conversion of $12 \%$ (entry 1 ). When HBEA was treated with oxalic acid at $\mathrm{pH} 3$ or $\mathrm{pH} 2$, the catalytic activity was improved and a larger conversion of $60 \%$ was achieved on the treatment at $\mathrm{pH} 2$ (entry 3). However, it was decreased on the oxalic acid treatment at lower $\mathrm{pH} 1.5$ and $\mathrm{pH} 1.0$, as compared to $\mathrm{pH} 2$ (entries 3-5). The product distribution also depended on the $\mathrm{pH}$ value of oxalic acid treatment. The active sample HBEA-pH2 shows a larger selectivity of $70 \%$ to the product $1,2-A c M O N$ compared with a selectivity of $60 \%$ for the parent HBEA sample (entries 1,3). Similar activity improvement and product distribution change were observed on the tartaric acid treatment at pH 2 (entry 8). In contrast, the steam treated HBEA samples did not influence the catalytic activity so much (entries 5,6). The removal of extra framework aluminum results in the increase in total pore volume (Table 1), implying the formation of clean pores. This may be the reason for the enhanced selectivity for the formation of 1,2-AcMON in the acid treated samples. In addition, the reusability of the active HBEA-pH2 catalyst was tested. The catalyst was removed from the reaction mixture after the first reaction, calcined at $500^{\circ} \mathrm{C}$ for $2 \mathrm{~h}$, and then reused for the second run under the same reaction conditions. It was found that the catalyst showed no change in the activity for the 
second reaction (Table 3, entry 9) and it had similar textural properties after the second run (Table 2). The XRD pattern of the reused HBEA-pH2 sample was identical to that of the fresh HBEA-pH2 sample, indicating its structural stability during the reaction (Fig. 7).

For the acylation reaction of naphthalene, the zeolite catalysts were less effective as compared with the acylation of 2-methoxynaphtalene. 2-acetyl naphthalene (2-AcN) was formed as major product and 1-acetyl naphthalene (1-AcN) as a minor product in the acylation reaction of naphthalene. Only HBEA-pH2, HBEApH1.5 and HBEA-pH2t were weakly active (Table 4, entries 3, 4, 7), while all the other catalysts were inactive.

\section{Table 3, Table 4, Figure 7}

The high activity of HBEA-pH2 and HBEA-pH1.5 can be correlated with the $\mathrm{NH}_{3}$-TPD results. As shown in Table 2, the amounts of weak acid sites are greatly different by a factor of 10 for these two samples and that of strong acid sites for the former is larger than that of the latter, which is in accordance with the difference in the activity. Careful inspection of the reaction (Table 3) and TPD (Table 2) results of all the samples dealuminated with oxalic and tartaric acids, suggests that the acylation reaction is mainly catalyzed by their strong acid sites. Further inspection of the $\mathrm{NH}_{3}$ TPD results suggest that all the acid sites are easily accessed by the small probe molecule of $\mathrm{NH}_{3}$, which in turn exhibit similar strong acidity in HBEA and HBEApH2 samples (Table 2, entries 1,3). However, some active sites that have been blocked by extra-framework $\mathrm{Al}$ species became active upon removal of these $\mathrm{Al}$ species by dealumination (Fig. 4 b-c). Removal of these site-blocking Al species by acid treatment results in more active sites which are accessible by large reactant molecules and increased the overall activity. Removal of these sites blocking $\mathrm{Al}$ species can also be correlated with the increase in the total surface area and total pore volume upon dealumination. Due to only a slight increase in strong acid sites (Table 2, $\mathrm{S} / \mathrm{W}$ ratio), only a marginal increase in activity was observed for steam treated sample.

The decrease in the number of acid sites with increasing framework $\mathrm{Si} / \mathrm{Al}$ ratio from 17 (HBEA) to 24.5 (HBEA-pH2) does not produce a decrease of catalyst 
activity but an increase in the overall activity, due to the strong acid sites. A further increase in the framework $\mathrm{Si} / \mathrm{Al}$ ratio to 30 produces a catalyst (for example HBEApH1.5) with very less number of actives sites, with the corresponding decrease of catalyst activity. The access of the bulky-reacting molecules to the catalytically active internal sites of the zeolites is controlled by the dimensions of the pore openings. The removal of extra-framework Al species results in clean pores and enhanced accessibility to the framework Al sites that are catalytically active strong acid sites. These structural changes enhanced the overall activity and selectivity.

Next, the activity of these catalysts was examined for esterification of benzyl alcohol with hexanoic acid. In this reaction, the ester was formed as a major product while dibenzyl ether was formed as a by-product due to a dehydrative condensation between two alcohol molecules. The results obtained are given in Table 5. The parent HBEA was moderately active with a conversion of $51 \%$ for this reaction (entry 1 ) and the most active catalyst was HBEA-pH2t with a conversion of $72 \%$ (entry 7). The differences in the activity among all the catalysts examined were not so large. From the results of Table 5 and Table 2, one may say that in this case also the strong acid sites are preferred active sites for the esterification reaction, similar to the acylation reaction (Table 3). The active catalyst HBEA-pH2 was shown to be recyclable without loss of activity for this reaction as well (Table 5, entry 8)

\section{Table 5}

\section{Conclusion}

The catalytic activity of beta zeolite can be enhanced by dealumination via acid and steam treatments, in which the acid treatments at controlled $\mathrm{pH}$ values are significantly effective. Upon oxalic acid treatments, extra-framework Al species blocking some framework $\mathrm{Al}$ sites were removed and then some framework $\mathrm{Al}$ species was also removed on further dealumination. The extra-framework Al species are responsible for weak acid sites, while the framework Al species for strong acid sites. The latter strong acid sites are efficient to catalyze the acylation and esterification reactions. Some active sites enveloped by extra-framework Al species can become effective upon removal of these Al species by dealumination. This causes 
an increase in the relative amount of strong acid sites and promotes the accessibility of large reactant molecules to the active sites, resulting in the enhancement of the overall activity of the zeolite beta catalyst.

Acknowledgements. The authors wish to express their thanks to Japan Society for the Promotion of Science for JSPS postdoctoral fellowship for RS (P07130) and for Grant-in-Aid for JSPS fellows (19·07130).

\section{References}

\begin{tabular}{|c|c|}
\hline [1] & Corma A, Garcia H (2003) Chem Rev 103: 4307. \\
\hline [2] & Corma A, Garcia H (2002) Chem Rev 102: 3837. \\
\hline [3] & Corma A (1997) Chem Rev 97: 2373. \\
\hline [4] & Corma A (1995) Chem Rev 95: 559. \\
\hline [5] & $\begin{array}{l}\text { Olah GA (1963) Friedel-Crafts and Related Reactions, Interscience } \\
\text { Publishers, New York, p. II. }\end{array}$ \\
\hline [6] & Stöcker M (2005) Micropo Mesopo Mater 82: 257. \\
\hline [7] & $\begin{array}{l}\text { Kiricsi I, Flego C, Pazzuconi G, Parker WO, Millini R Jr, Perego C, Bellussi } \\
\text { G (1994) J Phys Chem 98: 4627. }\end{array}$ \\
\hline [8] & $\begin{array}{l}\text { Bourgeat-Lami E, Massiani P, DiRenzo F, Espiau P, Fajula F (1991) Appl } \\
\text { Catal 72: } 139 .\end{array}$ \\
\hline [9] & Maache M, Janin A, Lavalley JC (1993) Zeolites 13: 419. \\
\hline [10] & Yang C, Xu Q (1997) Zeolites 19: 404. \\
\hline [11] & $\begin{array}{l}\text { Roberge DM, Hausmann H, Holderich WF (2002) Phys Chem Chem Phys 4: } \\
3128 .\end{array}$ \\
\hline [12] & Apelian MR, Degnan TF, Fung AS (1993) U.S. Patent 5,234,872. \\
\hline [13] & Saxton RJ, Crocco GL, Zajacek JG (1996) U.S. Patent 5,508, 019. \\
\hline [14] & $\begin{array}{l}\text { Apelian MR, Fung AS, Kennedy GJ, Degnan TF (1996) J Phys Chem 100: } \\
16577 .\end{array}$ \\
\hline [15] & Xie Z, Chen Q, Zhang C, Bao J, Cao Y (2000) J Phys Chem B 104: 2853. \\
\hline [16] & $\begin{array}{l}\text { Beyer HK, Belenykaja I (1980) In: Imelik B, C. NaccacheYBT, Vedrine JC, } \\
\text { Coudurier G, Praliaud H (Eds.), Catalysis by Zeolites, Studies in Surface } \\
\text { Science and Catalysis, Elsevier, Amsterdam, Vol 5, p } 203 .\end{array}$ \\
\hline
\end{tabular}




\begin{tabular}{|c|c|}
\hline [17] & Muller M, Harvey G, Prins R (2000) Micropor Mesopor Mater 34: 135. \\
\hline [18] & Rosenbach N Jr., Mota CJA (2008) Appl Catal A Gen 336: 54. \\
\hline [19] & Campbell SM, Jiang XZ, Howe RF (1999) Micropo Mesopo Mater 29: 91. \\
\hline$[20]$ & Treacy MMJ, Newsam JM (1988) Nature 332: 249. \\
\hline$[21]$ & Deem MW, Newsam JM, Creighton JA (1992) J Am Chem Soc 114: 7198. \\
\hline$[22]$ & $\begin{array}{l}\text { Van Bokhoven JA, Koningsberger DC, Kunkeler PJ, van Bekkum H, } \\
\text { Kentgens APM (2000) J Am Chem Soc 122: } 12842 .\end{array}$ \\
\hline [23] & $\begin{array}{l}\text { Kadgaonkar MD, Kasture MW, Bhange DS, Joshi PN, Ramaswamy V, Kumar } \\
\text { R (2007) Micropo Mesopo Mater 101: 108. }\end{array}$ \\
\hline [24] & $\begin{array}{l}\text { Jansen JC, Creighton EJ, Njo SL, van Koningsveld H, van Bekkum H (1997) } \\
\text { Catal Today 38: } 205 .\end{array}$ \\
\hline [25] & Yeh CY, Xu J, Angevine PJ (2008) USA Patent 7,371,910. \\
\hline$[26]$ & Skeels GW, Flanigen EM (1998) USA Patent 5,744,673. \\
\hline$[27]$ & Muler M, Harvey G, Prince R (2000) Micropo Mesopo Mater 34: 135. \\
\hline [28] & $\begin{array}{l}\text { Oumi Y, Mizuno R, Azuma K, Nawata S, Ffukushima T, Uozumi T, Sano T, } \\
\text { (2001) Micropor Mesopor Mater 49: } 103 .\end{array}$ \\
\hline [29] & $\begin{array}{l}\text { Oumi Y, Nemoto S, Nawata S, Fukushima T, Teranishi T, Sano T (2002) } \\
\text { Mater Chem Phys 78: 551. }\end{array}$ \\
\hline
\end{tabular}




\section{Figure Captions}

Fig. 1. XRD patterns of parent HBEA and HBEA samples dealuminated at (a) different $\mathrm{pH}$ conditions and (b) different steaming temperatures.

Fig. 2. ${ }^{27} \mathrm{Al}$ MAS NMR of parent HBEA and HBEA samples dealuminated at different $\mathrm{pH}$ conditions using oxalic acid.

Fig. 3. $\mathrm{NH}_{3}$-TPD patterns of parent and dealuminated HBEA samples. (a) HBEA, (b) HBEA-pH3, (c) HBEA-pH2, (d) HBEA-pH1.5, (e) HBEA-500 ${ }^{\circ}$, (f) HBEA- $400^{\circ} \mathrm{C}$, and (g) HBEA-pH2t.

Fig. 4. Schematic representation of HBEA samples before and after dealumination

Fig. 5. Influence of 2-methoxynaphthalene (2-MON)/acetic anhydride ratio on acylation reaction over HBEA-pH2 sample. Reaction conditions: 2-MON 10 mmol, 1,2dichloroethane $5.0 \mathrm{~g}$, catalyst $0.1 \mathrm{~g}$, temperature $150^{\circ} \mathrm{C}$, time $12 \mathrm{~h}$.

Fig. 6. Influence of solvents on acylation of 2-methoxynapthalene with acetic anhydride over HBEA-pH2 sample.

Fig. 7. XRD patterns of fresh and reused HBEA-pH2 samples. 

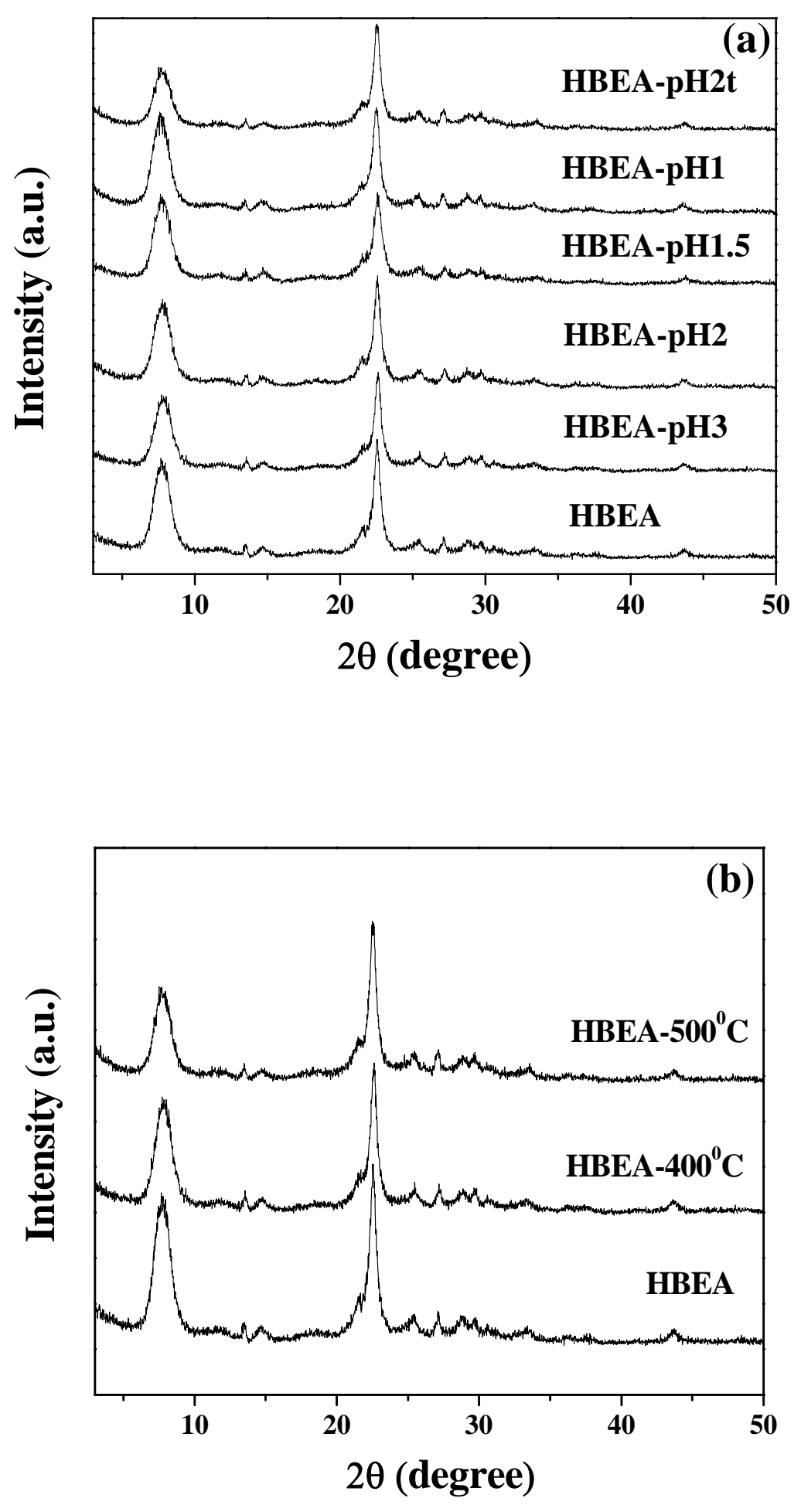

Fig. 1 
Table 1 Textural properties of various HBEA samples investigated in this study

\begin{tabular}{|c|c|c|c|c|c|c|}
\hline \multirow{2}{*}{ Sample } & \multirow{2}{*}{ Si/Al } & \multicolumn{3}{|c|}{$\begin{array}{c}\text { Surface area } \\
\left(\mathrm{m}^{2} / \mathrm{g}\right)\end{array}$} & \multicolumn{2}{c|}{$\begin{array}{c}\text { Pore volume } \\
\left(\mathrm{cm}^{3} / \mathrm{g}\right)\end{array}$} \\
\cline { 3 - 7 } & & Total & Micropore & External & Total & Micropore \\
\hline HBEA & 17.6 & 613 & 393 & 220 & 0.48 & 0.20 \\
\hline HBEA-pH3 & 20.0 & 632 & 381 & 251 & 0.56 & 0.19 \\
\hline HBEA-pH2 & 24.5 & 675 & 391 & 284 & 0.64 & 0.19 \\
\hline HBEA-pH1.5 & 30.2 & 686 & 400 & 286 & 0.61 & 0.20 \\
\hline HBEA-PH1 & Infinite & 694 & 408 & 286 & 0.63 & 0.19 \\
\hline HBEA-500 ${ }^{0} \mathrm{C}$ & 19.6 & 575 & 340 & 235 & 0.52 & 0.19 \\
\hline HBEA-400 ${ }^{0} \mathrm{C}$ & 17.6 & 605 & 379 & 226 & 0.47 & 0.19 \\
\hline HBEA-pH2t & 24.7 & 677 & 387 & 290 & 0.64 & 0.19 \\
\hline HBEA-pH2-reused & - & 665 & 390 & 275 & 0.62 & 0.20 \\
\hline
\end{tabular}




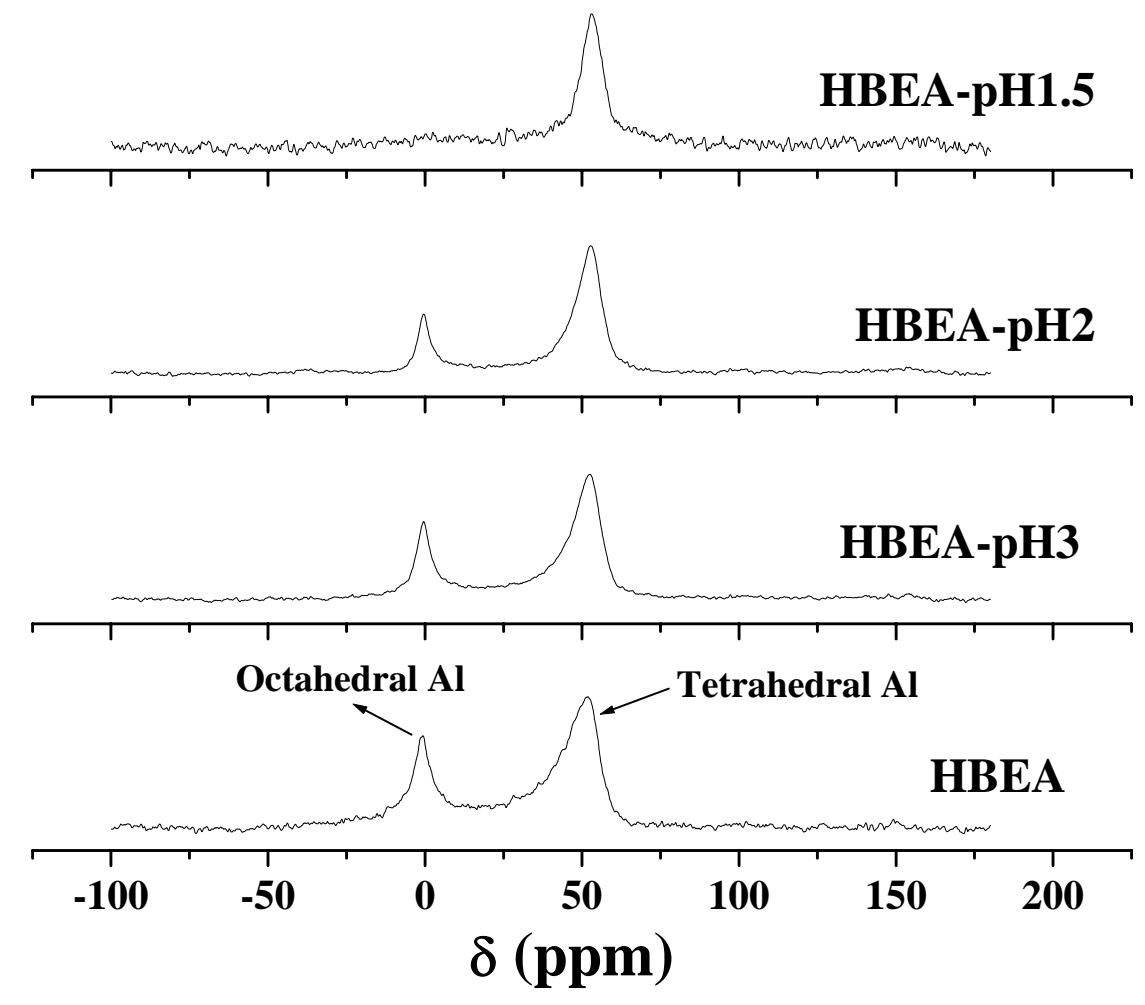

Fig. 2 
Table 2 Types of Al species and amounts of acid sites evaluated from ${ }^{27} \mathrm{Al}$ NMR and $\mathrm{NH}_{3}$-TPD measurements.

\begin{tabular}{|c|c|c|c|c|c|c|}
\hline \multirow{2}{*}{ Entry } & \multirow{2}{*}{ Sample } & Tetraherdal A1: & \multicolumn{4}{|c|}{ Amount of acid sites } \\
\cline { 5 - 8 } & & Octahedral Al & $\begin{array}{c}\text { Total } \\
(\mathrm{mmol} / \mathrm{g})\end{array}$ & $\begin{array}{c}\text { Weak } \\
(\mathrm{W})\end{array}$ & $\begin{array}{c}\text { Strong } \\
(\mathrm{S})\end{array}$ & $\mathrm{S} / \mathrm{W}$ \\
\hline 1 & HBEA & $74: 26$ & 0.82 & 0.44 & 0.38 & 0.87 \\
\hline 2 & HBEA-pH3 & $75: 25$ & 0.93 & 0.48 & 0.45 & 0.93 \\
\hline 3 & HBEA-pH2 & $81: 19$ & 0.67 & 0.30 & 0.37 & 1.23 \\
\hline 4 & HBEA-pH1.5 & $100: 0$ & 0.25 & 0.035 & 0.215 & 6.14 \\
\hline 5 & HBEA-500 ${ }^{\circ} \mathrm{C}$ & $76: 24$ & 0.76 & 0.39 & 0.37 & 0.95 \\
\hline 6 & HBEA-400 ${ }^{0} \mathrm{C}$ & $74: 26$ & 0.78 & 0.41 & 0.37 & 0.90 \\
\hline 7 & HBEA-pH2t & $81: 19$ & 0.66 & 0.29 & 0.37 & 1.27 \\
\hline
\end{tabular}




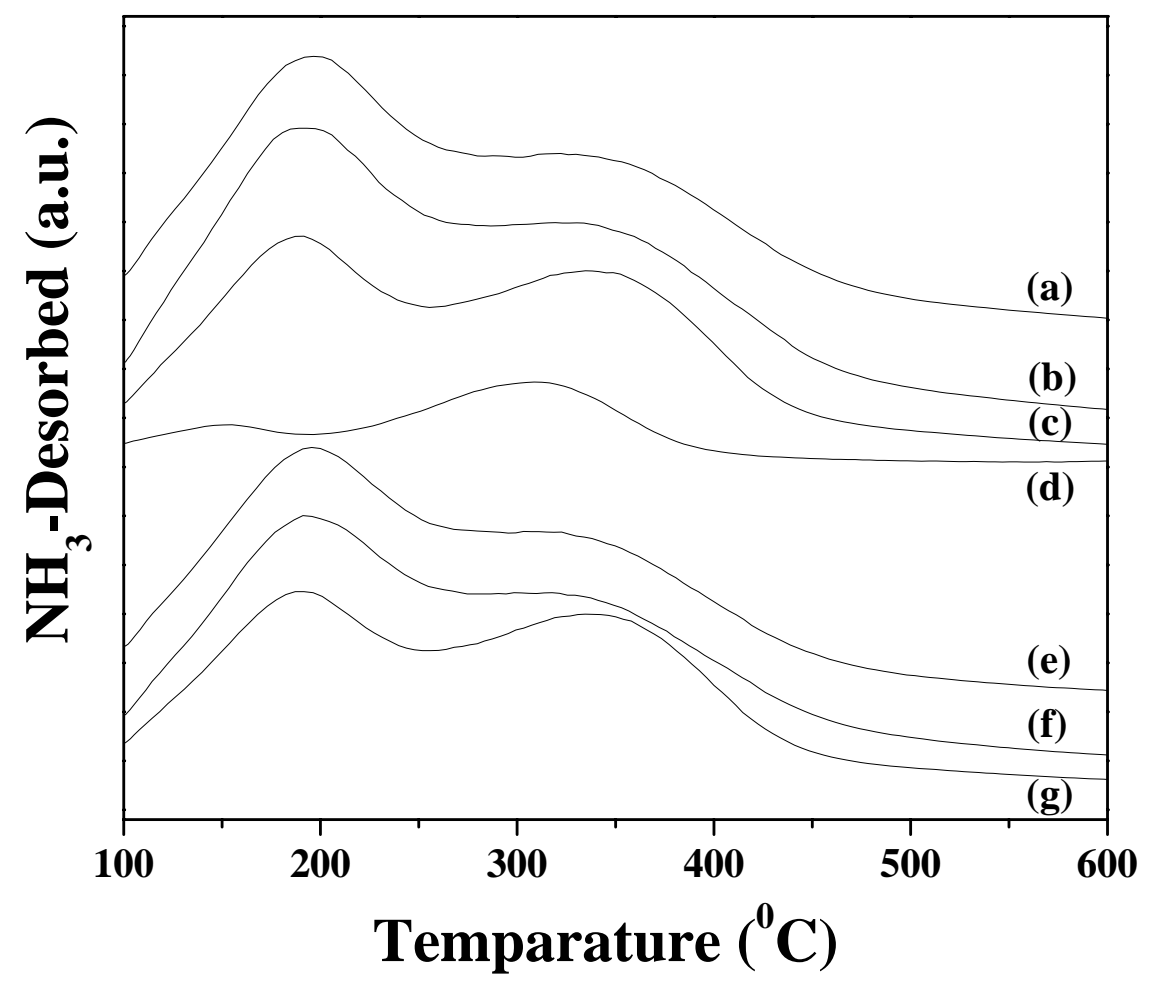

Fig. 3 


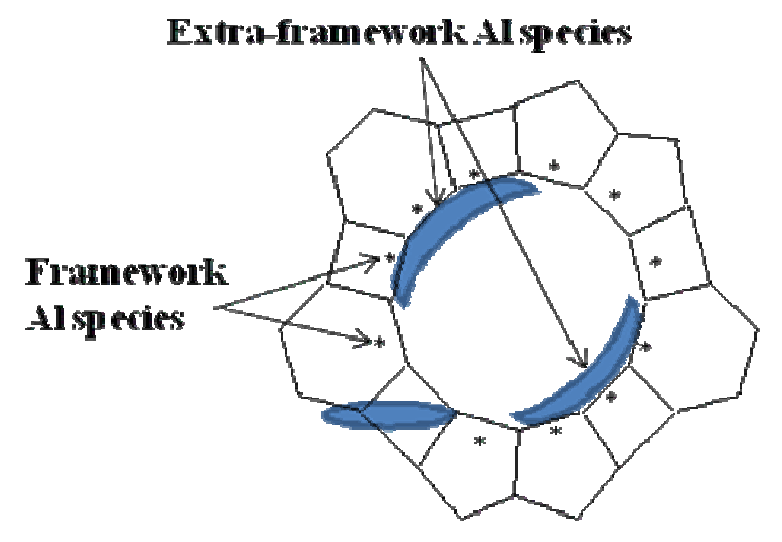

(a) HBEA

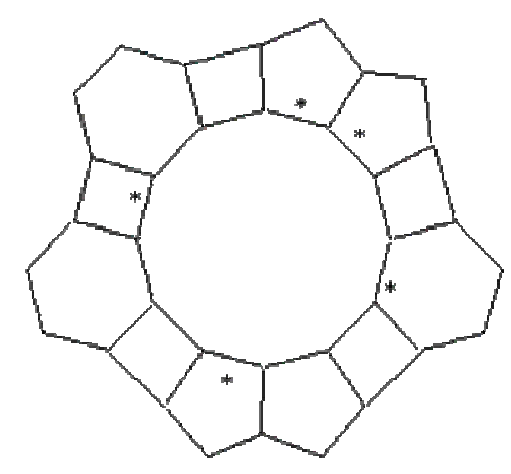

(c) HBE.A-pH1.5

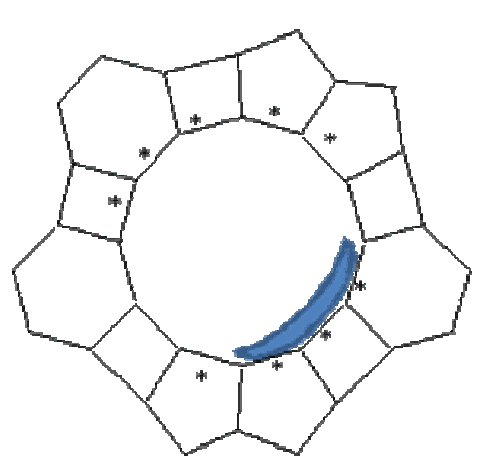

(b) HBEA-pH2

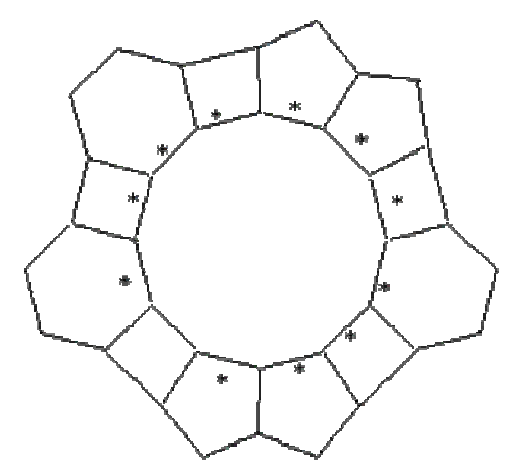

(d) Ideal dealumination of HBE. 1

Fig. 4 


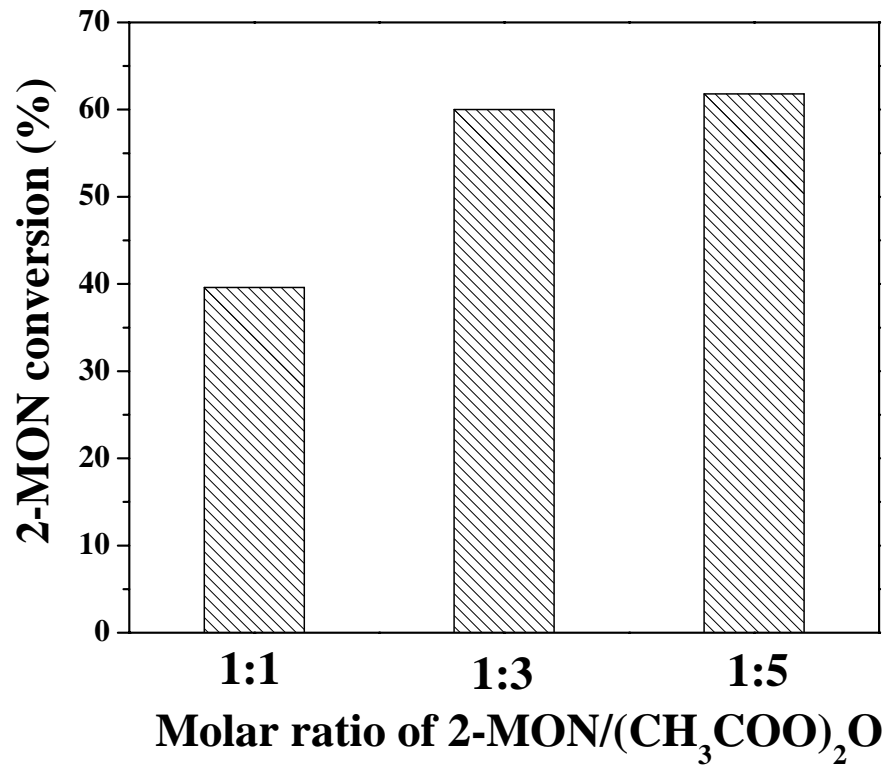

Fig. 5 


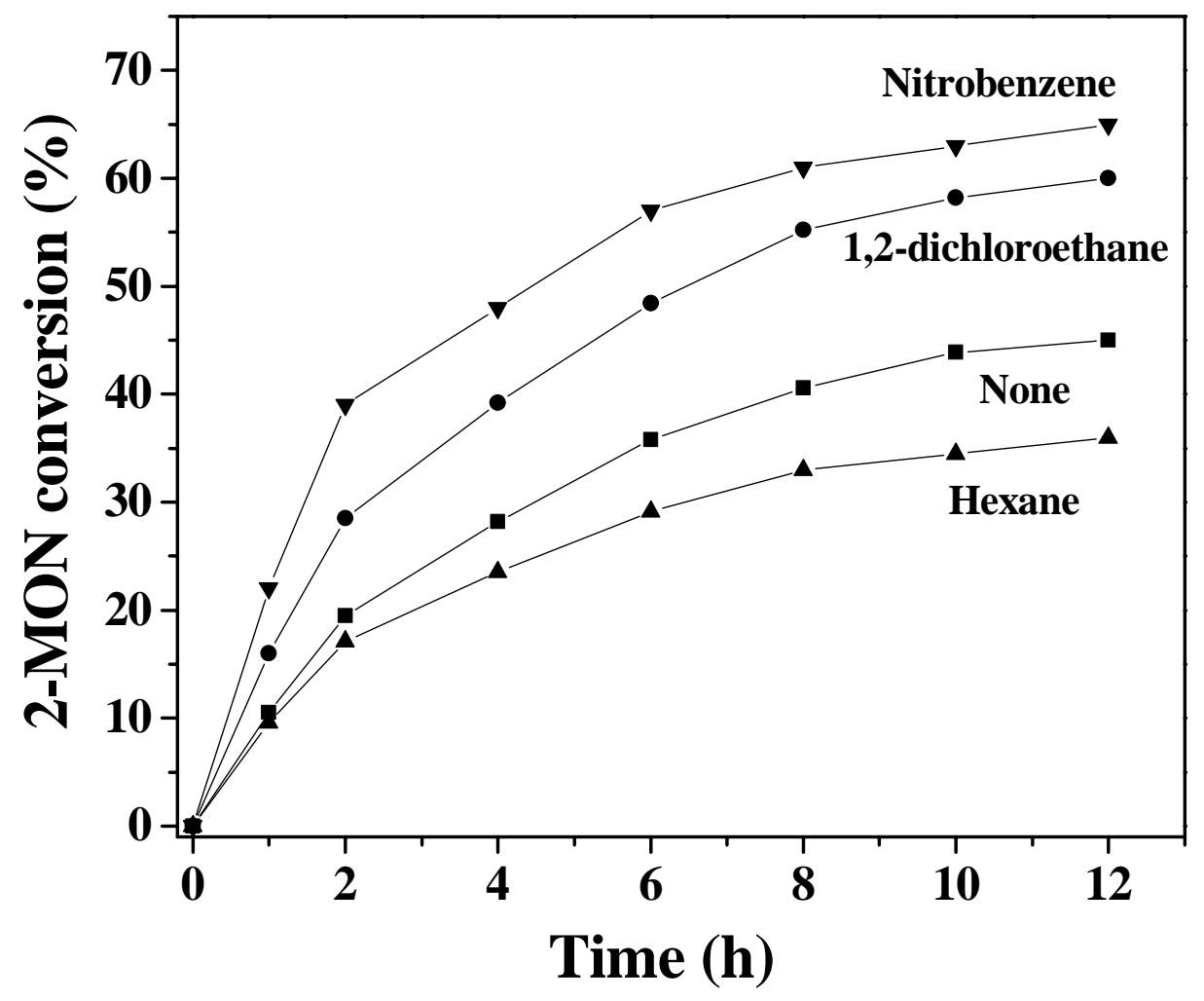

Fig. 6 


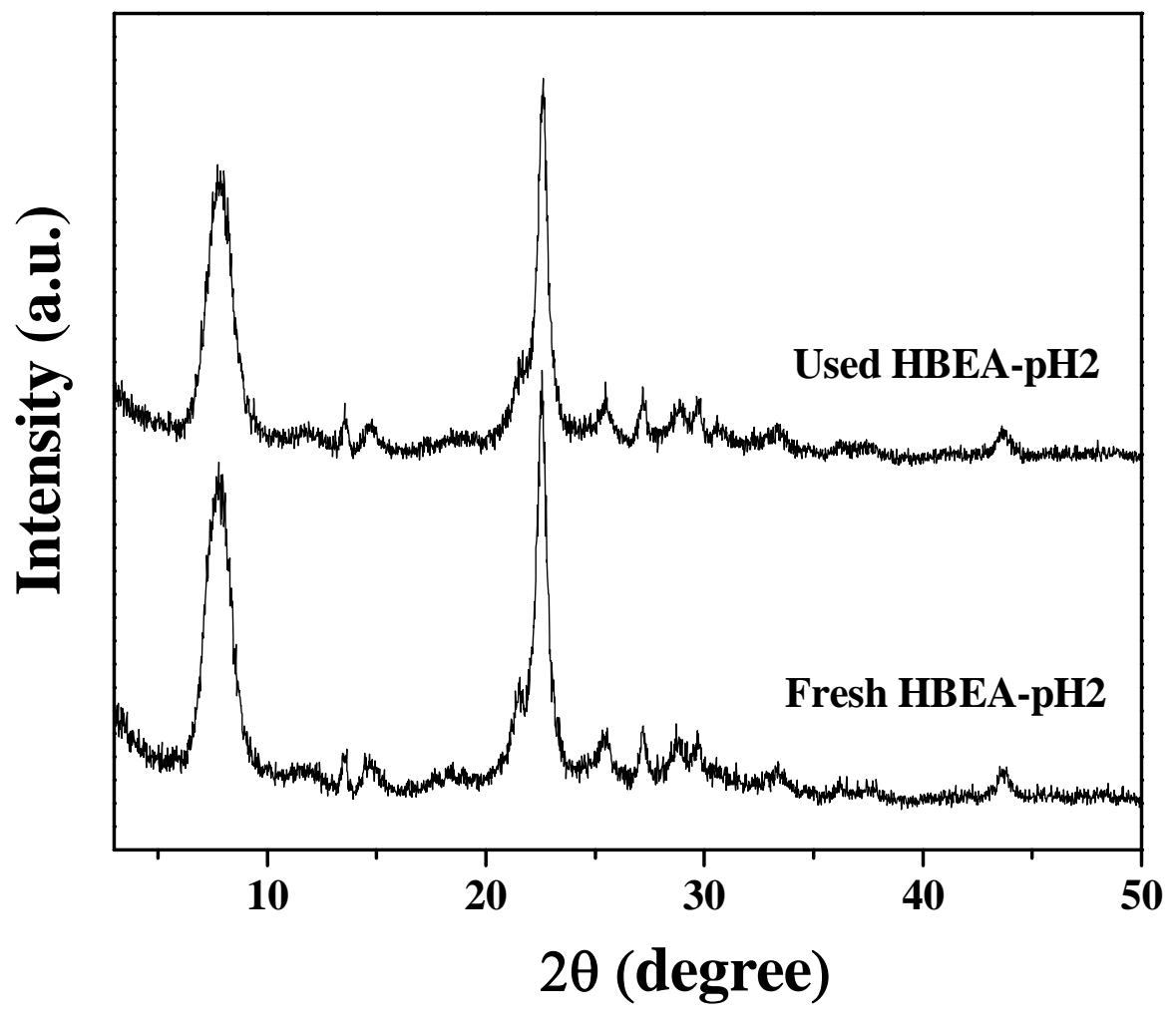

Fig. 7 
Table 3 Acylation of 2-methoxynaphthalene (2-MON) with acetic anhydride over HBEA samples treated at different conditions<smiles>COc1ccc2cc(C(=O)OCC(C)=O)ccc2c1</smiles>

\begin{tabular}{|c|c|c|c|c|c|c|}
\hline \multirow{2}{*}{ Entry } & \multirow{2}{*}{ Catalyst } & \multirow{2}{*}{$\begin{array}{c}\text { Conv. of } \\
\text { 2-MON }\end{array}$} & \multicolumn{2}{|c|}{ Product distribution (\%) } & \multirow{2}{*}{ TON } \\
\cline { 5 - 6 } & & $(\%)$ & $\begin{array}{c}1,2- \\
\text { AcMON }\end{array}$ & $\begin{array}{c}2,6- \\
\text { AcMON }\end{array}$ & others & \\
\hline 1. & HBEA & 11.6 & 60 & 36 & 4 & 12 \\
\hline 2. & HBEA-pH3 & 20.2 & 62 & 35 & 3 & 24 \\
\hline 3. & HBEA-pH2 & 60.0 & 70 & 27 & 3 & 89 \\
\hline 4. & HBEA-pH1.5 & 40.0 & 67 & 31 & 2 & 73 \\
\hline 5. & HBEA-pH1 & 3.3 & 70 & 27 & 3 & - \\
\hline 6. & HBEA-500 & 16.2 & 58 & 36 & 4 & 19 \\
\hline 7. & HBEA-400 & 12.5 & 61 & 35 & 4 & 13 \\
\hline 8. & HBEA-pH2t & 61.1 & 69 & 28 & 3 & 91 \\
\hline 9. & HBEA-pH2 & 62.2 & 69 & 29 & 2 & 93 \\
\hline & for the 2nd run & & & & & \\
\hline
\end{tabular}

Reaction conditions: 2-MON: $10 \mathrm{mmol}$; acetic anhydride: $30 \mathrm{mmol}$; 1,2dichloroethane: $5.0 \mathrm{~g}$; catalyst: $0.1 \mathrm{~g}$; temperature: $150^{\circ} \mathrm{C}$; reaction time: $12 \mathrm{~h}$. $\mathrm{TON}=$ moles of reactant converted per mole of catalyst 
Table 4 Acylation of naphthalene with acetic anhydride over HBEA samples treated at different conditions.<smiles>c1ccc2ccccc2c1</smiles>

$+\left(\mathrm{CH}_{3} \mathrm{CO}\right)_{2} \mathrm{O}$<smiles>CC(=O)c1ccc2ccccc2c1</smiles>

2-AcN<smiles>CC(=O)c1cccc2ccccc12</smiles>

1-AcN

\begin{tabular}{|c|c|c|c|c|c|}
\hline Entry & Catalyst & Conv. Of & \multicolumn{2}{|c|}{ Product distribution } & \multirow{2}{*}{ TON } \\
\cline { 4 - 5 } & & naphthalene (\%) & 2-can & 1-can & \\
\hline 1. & HBEA & Nil & - & - & - \\
\hline 2. & HBEA-pH3 & 0.5 & 80 & 20 & $<1$ \\
\hline 3. & HBEA-pH2 & 5.2 & 76 & 24 & 8 \\
\hline 4. & HBEA-pH1.5 & 2.8 & 75 & 25 & 5 \\
\hline 5. & HBEA-500 $\mathrm{C}$ & 0.3 & 80 & 20 & $<1$ \\
\hline 6. & HBEA-400 ${ }^{\circ} \mathrm{C}$ & Nil & - & - & - \\
\hline 7. & HBEA-pH2t & 5.6 & 76 & 24 & 8 \\
\hline
\end{tabular}

Reaction conditions: Naphthalene: $10 \mathrm{mmol}$; acetic anhydride: $30 \mathrm{mmol}$; 1,2dichloroethane: $5.0 \mathrm{~g}$; catalyst: $0.1 \mathrm{~g}$; temperature: $150^{\circ} \mathrm{C}$; reaction time: $12 \mathrm{~h}$.

$\mathrm{TON}=$ moles of reactant converted per mole of catalyst 
Table 5 Esterification of benzyl alcohol with hexanoic acid over HBEA samples treated at different conditions.<smiles>OCc1ccccc1</smiles><smiles>CCCCCC(=O)O</smiles><smiles>C1CCC1</smiles><smiles>CCCCCC(=O)OCc1ccccc1</smiles>

Ether

\begin{tabular}{|c|c|c|c|c|}
\hline \multirow{2}{*}{ Entry } & \multirow{2}{*}{ Catalyst } & Conv. Of benzyl & \multicolumn{2}{|c|}{ Product distribution (\%) } \\
\cline { 4 - 5 } & alcohol (\%) & Ester & Ether \\
\hline 1. & HBEA & 51.3 & 73 & 27 \\
\hline 2. & HBEA-pH3 & 58.0 & 71 & 29 \\
\hline 3. & HBEA-pH2 & 70.0 & 65 & 35 \\
\hline 4. & HBEA-pH1.5 & 60.5 & 60 & 40 \\
\hline 5. & HBEA-500 ${ }^{0} \mathrm{C}$ & 56.2 & 70 & 30 \\
\hline 6. & HBEA-400 ${ }^{\circ} \mathrm{C}$ & 50.7 & 74 & 26 \\
\hline 7. & HBEA-pH2t & 71.5 & 66 & 34 \\
\hline 8. & HBEA-pH2 & 71.4 & 72 & 28 \\
\hline
\end{tabular}

Reaction conditions: Hexanoic acid: $10 \mathrm{mmol}$; benzyl alcohol: $10 \mathrm{mmol}$; toluene: $2.5 \mathrm{~g}$; catalyst: $0.1 \mathrm{~g}$; temperature: $130^{\circ} \mathrm{C}$; reaction time: $4 \mathrm{~h}$. 